\title{
Late Jurassic-Early Cretaceous kimberlite, carbonatite and ultramafic lamprophyric sill and dyke swarms from the Bomethra area, northeastern Oman
}

\author{
S. Nasir ${ }^{(1)}$, S. Al-Khirbash ${ }^{(1)}$, H. Rollinson ${ }^{(1)}$, A. Al-Harthy ${ }^{(1)}$, A. Al-Sayigh ${ }^{(1)}$, A. \\ Al-Lazki $^{(1)}$, E. Belousova ${ }^{(2)}$, F. Kaminsky ${ }^{(3)}$, T. Theye ${ }^{(4)}$, H.-J. Massonne ${ }^{(4)}$, S. Al-Busaidi ${ }^{(5)}$ \\ ${ }^{1}$ Department of Earth Sciences, Sultan Qaboos University, Oman \\ ${ }^{2}$ GEMOC ARC National Key Centre, Macquarie University, Australia \\ ${ }^{3}$ KM Diamond Exploration Ltd, Vancouver, Canada \\ ${ }^{4}$ Institut für Mineralogie und Kristallchemie, Universität Stuttgart, Germany \\ ${ }^{5}$ Directorate General of Minerals, Oman
}

The Batain Nappes in Oman is represented by an allochthonous unit mainly consists of sedimentary rocks with subordinate volcanic rocks and minor intrusions, deposited in the Batain Basin along the eastern Oman continental margin during the Permian to the Late Cretaceous times. The allochthonous units in the Batain Plain were emplaced in a NW direction on to the Arabian plate at the Cretaceous/Tertiary boundary. The Nappes contain ophiolite, ultramafic lamprophyres, carbonatite and kimberlites occurring as pipes in the Asseelah area and as plugs, sills and dykes of several meters thick and about $6 \mathrm{~km}$ long in the Bomethra area. The majorities of these rocks are hosted by the Late Jurassic to Early Cretaceous Wahra Formation, which comprises a series of radiolarian cherts, shales and clay stones, and are found over the whole Batain plain.

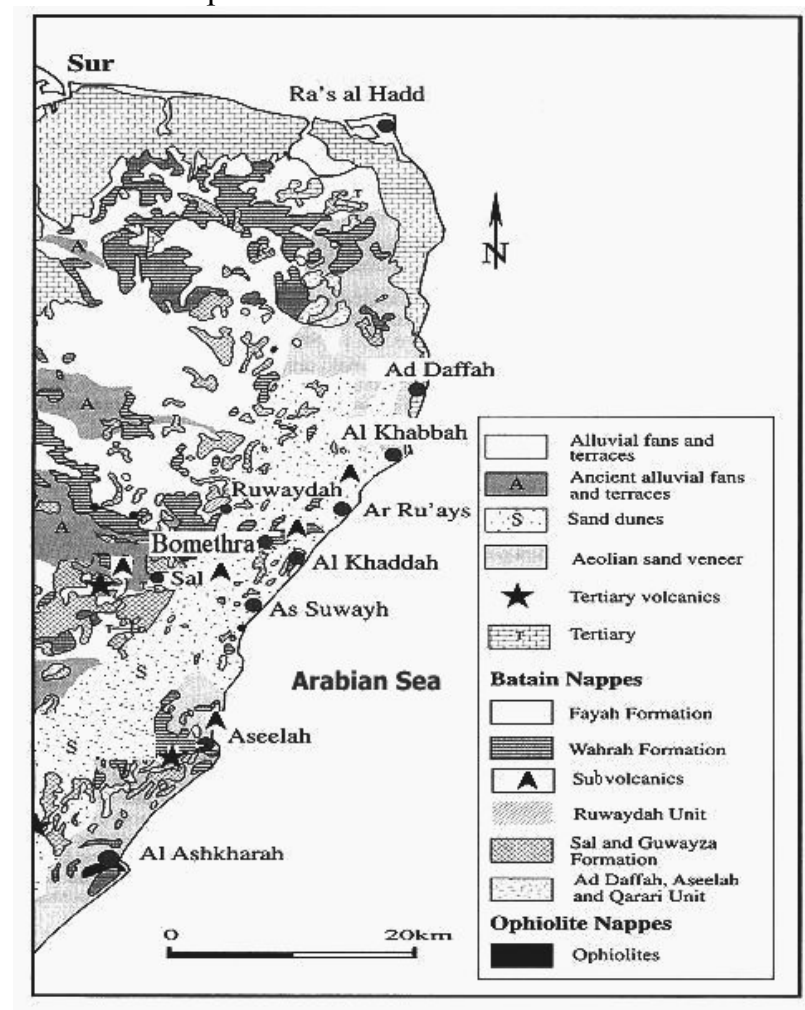

\section{Petrography and Mineralogy}

The dyke and sill swarms are located approximately 20 $\mathrm{km}$ northeast of the Aseelah pipe (Nasir et al., 2008) in the Bometrha area (Map above). The main sill has a thickness of $1-2 \mathrm{~m}$ and extends to $6 \mathrm{~km}$ in $\mathrm{N} 40^{\circ} \mathrm{E}$ direction. Two blows, 200x500 m exposure of effusive rocks occur within the main sill. They are composed of lapilli and bombs, mixed with pieces of radiolarian cherts.

Two varieties of ultramafic rocks have been observed: one is medium- to coarse-grained mica-carbonate-rich damtjernite with abundant calcite-ocelli and/or pelletal lapilli, and the other is massive fine-grained tuffitic aillikite (Figures below). Microscopically, the damtjernite exhibits a range of textures from welldeveloped segregations of calcite and phlogopite with abundant microlitic apatite and phlogopite, to the more typical, well-developed pelletal texture.

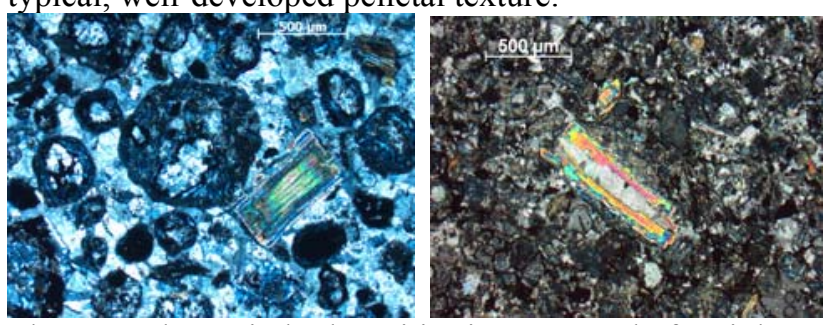

The groundmass in both verities is composed of mainly of calcite, phlogopite, and apatite. Cr-Spinel, magnetite and rutile are common. Orthoclase, diopside and richterite occur mainly in the damtjernite.

Carbonate typically occurs together with phlogopite and apatite as fine-grained $(<0.1 \mathrm{~mm})$ aggregates of xenomorphic grains in the ground mass. Primary Srbearing calcite $(0.1$ to $0.15 \mathrm{wt} . \%)$ is the dominant carbonate phase and is commonly present in the groundmass of all samples.

Apatite is a late-crystallizing groundmass phase. The grains are euhedral, prismatic with hexagonal base sections. Abundant apatite occurs as acicular grains and as larger more prismatic grains grown primarily within calcite segregations. They are relatively Si-rich (0.9-1.8 wt $\left.\% \mathrm{SiO}_{2}\right)$ and $\mathrm{Sr}$-poor $(<1.5 \mathrm{wt} \% \mathrm{SrO})$. 
Phlogopite is a major constituent in the Bomethra ultramafic rocks, generally forming $>30 \mathrm{vol} . \%$ of the mineral assemblage. It occurs as euhedral six-sided macrocryst, phenocrysts, and unhedral microphenocrysts and as small groundmass crystals characterized by subhedral to euhedral laths $(0.05$ to $0.1 \mathrm{~mm})$. The phlogopite is titania aluminous and plots along a trend described for minette and alnöite rocks (Mitchell, 1986) (Figure below).

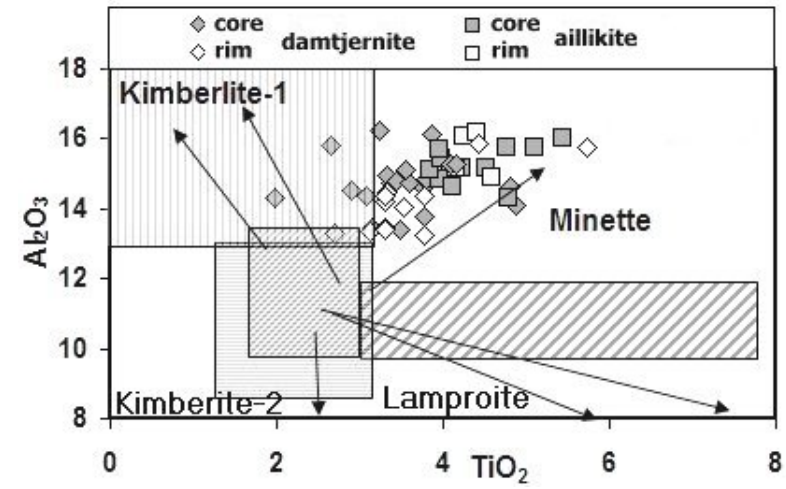

Spinel is a ubiquitous mineral phase in all samples. It occurs as macrocrysts, primary groundmass minerals, and occasionally in association with ilmenite and rutile. Small $(<0.2 \mathrm{~mm})$ euhedral-to-subhedral spinels comprise a significant portion of the groundmass mineral assemblage of both aillikite and damtjernite $\mathrm{TiO}_{2}$ contents are typically $<1$ wt. $\%$, increasing with evolution to as high as $\approx 11.5$ wt.\%. Two separate evolutionary trends of primary magmatic groundmass spinels are found: magnesian ulvöspinel magmatic trend (trend 1) and titanomagnetite magmatic trend (trend 2). The former occurs in the aillikite groundmass spinels, while the latter is characteristic only of damtjernite (Figures below).
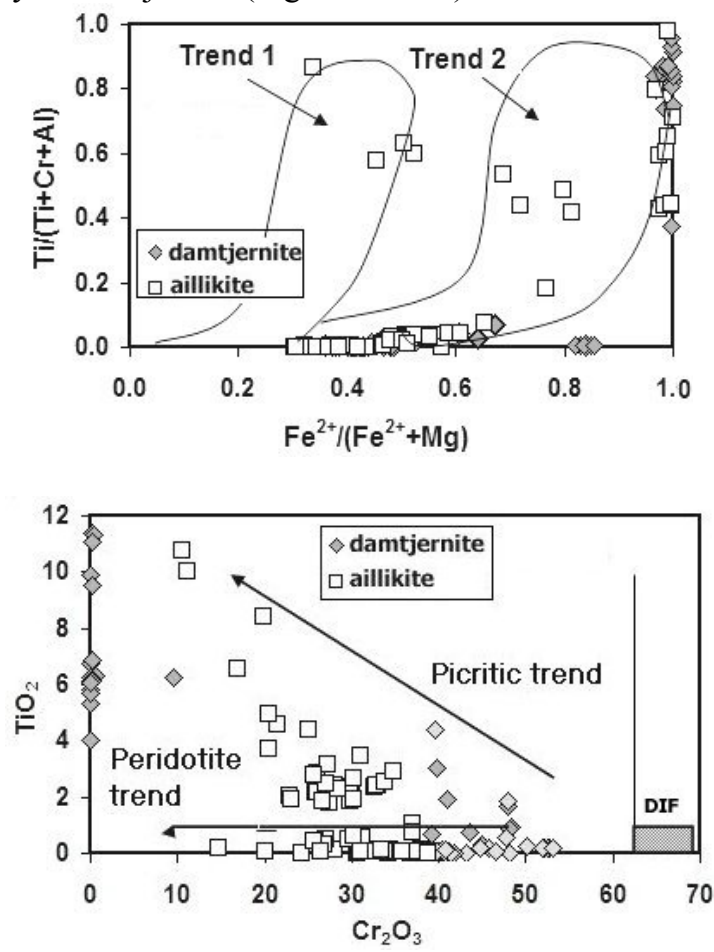

One forsteritic olivine grain and one G4 garnet grain, beside abundant chromite grains were recovered from the heavy mineral concentrates. Garnet grain has a size of $0.43 \times 0.35 \mathrm{~mm}$. It is a spalled, oval-flattened, pale yellow-orange grain. Pure orthoclase occurs only in the damtjernite.

Cr-diopside and richterite occur sporadically in the carbonate groundmass. Diopside form the damtjernite has lower $\mathrm{A} 12 \mathrm{O} 3$ and $\mathrm{Na} 2 \mathrm{O}$ than those from the aillikite (Figure below). Rutile, chlorite and serpentine are common accessory minerals.

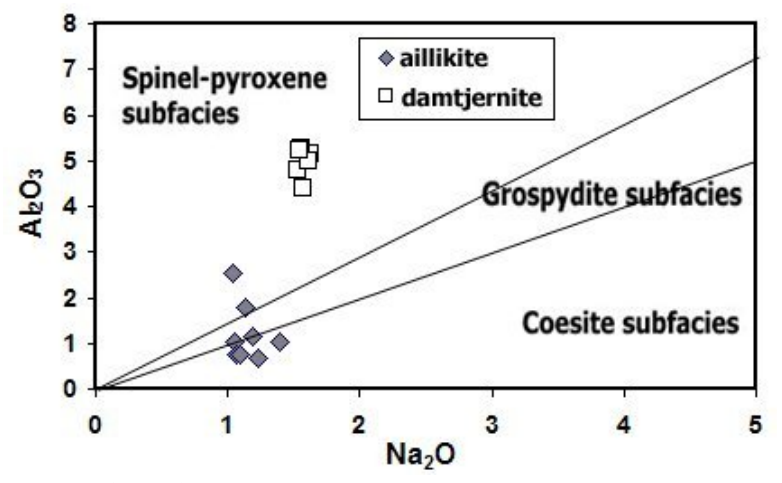

\section{P-T estimation}

The crystallization pressure of clinopyroxene as estimated by the clinopyroxene barometer of Nimis (1995) can be bracketed between 1.3 and $2.4 \mathrm{GPa}$ for the damtjernite and between 24-29 GPa for the aillikite. Temperatures vary between 680 and $890^{\circ} \mathrm{C}$ for the damtjernite and between $840-940^{\circ} \mathrm{C}$ for the aillikite, (Figure below).

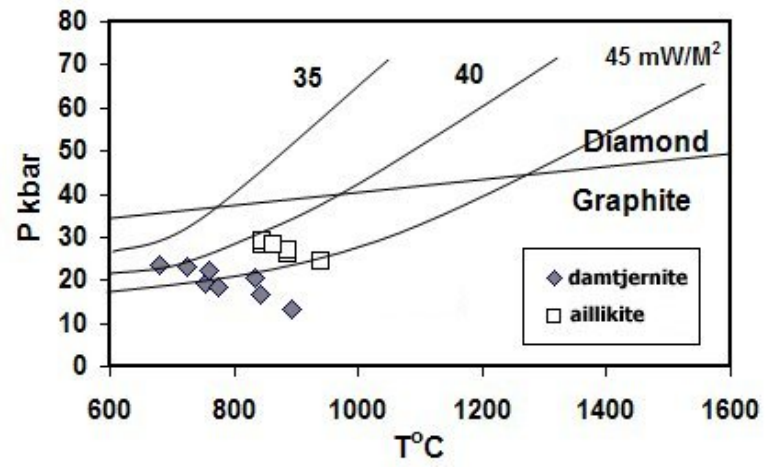

\section{Whole Rock Geochemistry}

The Bomethra rocks are strongly silica undersaturated (1734 wt. $\% \mathrm{SiO}_{2}$ ), with high $\mathrm{Al}_{2} \mathrm{O}_{3}$ (3.5-9.5 wt.\%) and variable $\mathrm{TiO}_{2}$ (1-3 wt.\%). They have low $\mathrm{MgO}$ (5-11 wt. $\%$ ), which never approach $\mathrm{MgO}$-values similar to kimberlites. The Bomethra rocks have petrographic and geochemical affinities with aillikite. On the $\mathrm{FeO}_{\mathrm{t}}-\mathrm{MgO}$ $\mathrm{Al}_{2} \mathrm{O}_{3}$ ternary discriminant plot, and $\mathrm{SiO} 2$ vs. selected major elements (Figures left below), these rocks generally fall in the aillikite field.

The incompatible trace element abundances show a significant enrichment in most elements, particularly $\mathrm{Nb}$, Ta and LREEs and pronounced troughs at $\mathrm{Rb}, \mathrm{K}, \mathrm{Pb} . \mathrm{P}$, Hf, and Ti (Figure left below). 

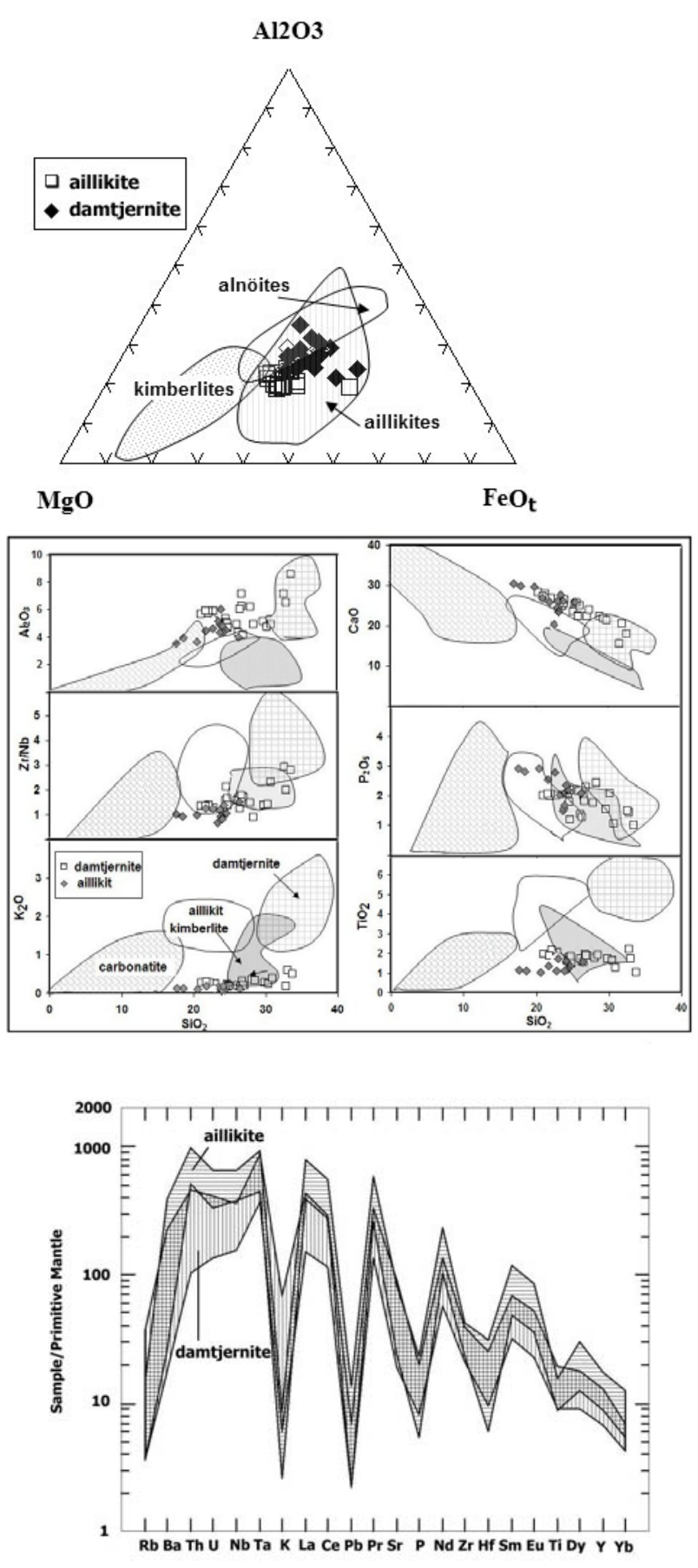

The REE patterns are all remarkably similar and show strong LREE enrichment with $\mathrm{La}_{\mathrm{n}} / \mathrm{Yb}_{\mathrm{n}}$ between 30-70 (Figure below).

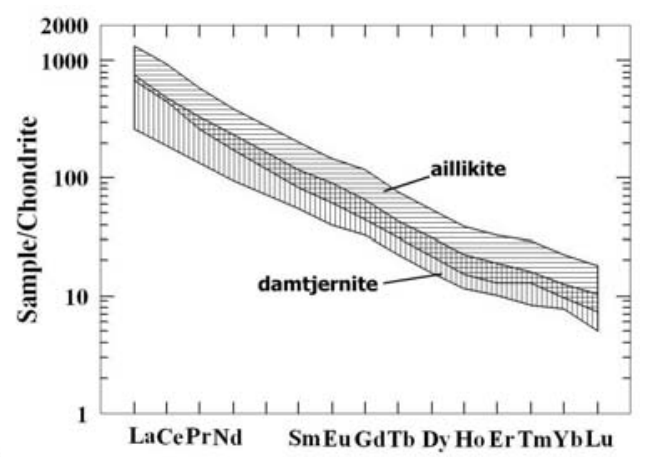

K-Ar whole rock age dating yielded an age between 130$140 \mathrm{Ma}$, similar to that of the Asseelah aillikites and carbonatites (Nasir et al., 2008). The initial Sr, Nd and $\mathrm{Pb}$ isotope compositions of the aillikite and damtjernite have strong affinity with ultramafic lamprophyres and are similar to the Reunion mantle plume

\section{Discussion}

The Bomethra rocks show very low $\mathrm{SiO}_{2}$ and $\mathrm{MgO}$ contents, much lower than most common alkaline magmas. They have petrographic and geochemical affinities with aillikite, damtjernite, and kimberlite, and resemble experimentally produced melts of synthetic carbonated garnet peridotite in the simple $\mathrm{CMAS}-\mathrm{CO}_{2}$ system close to $3 \mathrm{GPa}$. The high abundance of REE and most incompatible elements may be interpreted as a result of derivation from a lower degree of partial melts or due to enrichment in the mantle source. The $\mathrm{K}$ and $\mathrm{Ti}$ depletions may be related to a residual phlogopite phase in the source mantle during partial melting. The abundance of magmatic carbonate suggests that the primary magmas were derived from a carbonated mantle. The initial $\mathrm{Sm}-\mathrm{Nd}$ and $\mathrm{Pb}$ isotope are close to the value of the Reunion mantle plume.

There is no obvious age progression for the various types of magmatic activity in the Batain Nappes. It is quite possible, therefore, that all of the magmatic rocks seen in the Batain plain originated in a single event, triggered by the arrival of upwelling mantle plume beneath the metasomatised Indo-Arabian lithosphere. The influx of heat cause melting of the carbonated garnet peridotite asthenospheric mantle forming carbonatite, aillikite, damtjernite and other more fractionated alkaline magmas. The Late Jurassic-Early Cretaceous magmatism in eastern Oman is related spatially and compositionally to mantle upwelling associated with the Reunion mantle plume.

\section{References}

Mitchell, R. H., 1986. Kimberlites: Mineralogy, Geochemistry and Petrology, Plenum, New York

Nasir'S., Al-Khirbash, S, Rollinson, H., Al-Harthy, A., Al-Sayigh, A., Al-Lazki, A., E. Belousova, E.

Kaminsky, F., Theye, T., Massonne'H-J., AlBusaidi, S. 2008. Evolved carbonatitic kimberlite from the Batain Nappes, eastern Oman continental margin. 9IKC-A- 00002.

Nimis, P 1995. A clinopyroxene geobarometer for basaltic systems based on crystal-structure modeling. Contribution to Mineralogy and Petrology, 121, 115-125 